Boston University School of Law Scholarly Commons at Boston University School of Law

Faculty Scholarship

$12-2013$

\title{
Essay: Resolving the Public Pension 'Crisis'
}

Jack M. Beermann

Boston University School of Law

Follow this and additional works at: https://scholarship.law.bu.edu/faculty_scholarship

Part of the State and Local Government Law Commons

\section{Recommended Citation}

Jack M. Beermann, Essay: Resolving the Public Pension 'Crisis', No. 14-5 Boston University School of Law, Public Law Research Paper (2013).

Available at: https://scholarship.law.bu.edu/faculty_scholarship/143 


\title{
BU School of Law
}

\section{Essay: Resolving the Public Pension “Crisis”}

Boston University School of Law Working Paper No. 14-5

(January 21, 2014)

\author{
Jack M. Beermann \\ Boston University School of Law
}

This paper can be downloaded without charge at:

http://www.bu.edu/law/faculty/scholarship/workingpapers/2014.html 
Beermann, Resolving the Public Pension “Crisis”, 11/11/2013

Essay: Resolving the Public Pension "Crisis"

\section{Jack M. Beermann ${ }^{*}$}

The public pension pigeons are coming home to roost. The high profile bankruptcy filing by the City of Detroit, Michigan, has brought to the fore the relationship between pension underfunding and the financial difficulties faced by an increasing number of municipalities and states in the United States. The problem is likely to continue to grow with more municipalities finding it necessary to explore the bankruptcy option. It has even been suggested that states be allowed to use bankruptcy to reduce their pension liabilities. ${ }^{1}$ Trillions of dollars owed for promises to millions of current and retired public employees are at stake.

Scholarship concerning the public pension crisis has focused on disagreements over actuarial calculations and the legal principles that constrain state and local pension reform. While there is no doubt that pension liabilities are an important contributing factor to the fiscal difficulties of municipalities like Detroit, disagreement remains concerning the magnitude of the problem nationwide. On the fiscal side, some analysts contend that major reform is necessary to avert a widespread fiscal crisis while others conclude that moderate change would be sufficient to resolve the fiscal difficulties faced by most public pension plans. On the legal side, some

\footnotetext{
* Professor of Law and Harry Elwood Warren Scholar, Boston University School of Law. Thanks to the Fordham Urban Law Journal for inviting me to participate in the Cooper-Walsh Colloquium for which this essay was prepared. Thanks also to the participants in the colloquium for their helpful suggestions on this essay, including Clayton Gillette, Patricia Salkin and Paul Secunda. This essay is dedicated to the memory of Irving "Pro" Boim, a lifetime public school teacher in Ann Arbor, Michigan, who epitomized the public servant earning a pension through dedicated service.

${ }^{1}$ David A. Skeel, Jr., States of Bankruptcy, 79 U. Chi. L. Rev. 677 (2012).
} 
Beermann, Resolving the Public Pension "Crisis”, 11/11/2013

analysts bemoan the straitjackets that many public entities find themselves in due to state law that severely limits pension reform, while others claim that there is sufficient legal flexibility to accommodate necessary reforms. Little attention has been focused on the workers and retirees who are likely to suffer if their current or future payments are reduced substantially in order to restore their current or former employers to fiscal health.

In an earlier, comprehensive article, The Public Pension Crisis, ${ }^{2}$ I addressed many of the issues surrounding widespread underfunding of public pension liabilities at the municipal and state levels in the United States. Although there is no question that many governmental units have fallen far short of the actuarially sound contribution levels to their pension funds, I noted that there is significant disagreement over whether this underfunding presents a true fiscal crisis. While some analysts claim that many states and cities may be insolvent, others conclude that modest increases in pension contributions would resolve the problem. Further, in tight fiscal times, many state and local governments have cut payments to pension funds to balance the budget.

I then explored whether public pension promises are excessive or abusive, and if so why would government promise excessive pensions. It turns out that this is controversial as well, with some analysts concluding that overall compensation to public employees is significantly higher than compensation in the private sector while others concluding that, if anything, public employees are underpaid and better pensions are part of a tradeoff involving lower salaries. I noted that incumbent politicians often depend on government employees for political support, and even if only a small percentage of public employees are politically connected, favorable

2 Jack M. Beermann, The Public Pension Crisis, 70 Wash. \& Lee L. Rev. 3 (2013). 
Beermann, Resolving the Public Pension "Crisis”, 11/11/2013

compensation including pensions would likely be provided to all employees if only to boost the fortunes of the small, favored group. Further, underfunding pensions is a form of deficit spending under which current taxpayers enjoy services that are paid for by later taxpayers. I also illustrated that there are plenty of cases of abusive conduct in the public pension arena, but it is not clear whether the fact that there are some abuses means that the whole system should be viewed with suspicion.

I then looked at legal constraints on public pension reform under state and federal law. The weight of state constitutional law in many states is on the side of government employees and retirees. Many state constitutions have provisions protecting pension rights that have been interpreted to prohibit significant reductions in pension promises to existing employees and retirees. State and local pension reform is also constrained by the Contract Clause of the United States Constitution, which prohibits state laws that impair the obligation of contracts. In recent times, this provision has been interpreted to apply most strongly to states' efforts to breach their own contracts. Municipal bankruptcy under Chapter 9 of the Federal Bankruptcy Code may provide an avenue of pension reform for some insolvent municipalities. State governments cannot employ bankruptcy, but there is a chance that if a state decides to default on its pension obligations, the federal courts would be powerless to order a remedy. ${ }^{3}$

My article concluded with a normative discussion of the plight of state employees and retirees. Unless one believes that the average state employee has been part of an abusive conspiracy to inflate pensions at taxpayers' expense, there is a strong normative case to be made

\footnotetext{
${ }^{3}$ For a discussion of the eleventh amendment issues surrounding damages remedies for state Contract Clause violations, see Beermann, supra note $\mathrm{x}$ at $78-84$.
} 
Beermann, Resolving the Public Pension "Crisis”, 11/11/2013

for relief aimed at preserving pension rights. State employees accepted lower current pay in exchange for job security and favorable retirement promises, and for those who were not part of the federal Social Security system, their state or local pension may be their only source of retirement income. Even well-paid state and local government workers may have decided to accept government employment or remain in government employment when other opportunities arose in reliance on attractive pension promises. Public pensions constitute contractual compensation not gratuities, and in the normal case, there is a strong argument that government units should be required to live up to these promises.

This essay is an effort to provoke discussion of the normative issues surrounding pension reform, mainly concerning how public employees and retirees should be treated. Should pension claimants be treated like any other unsecured creditor, or any other person who suffers when the regulatory background is altered, or is there a case for treating them as victims of a fiscal disaster beyond their control? Is pension reform just one more step in the evolution of the labor market that has made it much more difficult for lower skilled workers to achieve a middle class lifestyle? If so, how should the law react? The essay also includes some discussion of the fascinating federalism issues raised by the potential clash between state law protecting pension rights and federal bankruptcy standards. Should a federal bankruptcy court respect the decision of a state court, that the use of federal bankruptcy to reduce pension obligations would violate state constitutional protection of pension rights? This may be the most interesting federalism dispute in decades.

I. 
Beermann, Resolving the Public Pension “Crisis", 11/11/2013

Recent developments, particularly the bankruptcies of Central Falls, Rhode Island, and Detroit, Michigan, should create unease over fairness and utility of municipal bankruptcy. In the Central Falls bankruptcy, pension payments to existing retirees were cut by 55 per cent, while municipal general obligation bondholders were paid in full. This may be surprising since pension claimants and general obligation bondholders are usually both unsecured creditors, normally entitled to the same level of compensation in bankruptcy. Full payment to bondholders was apparently justified by fear of the negative impact on the ability of Rhode Island municipalities to sell bonds in the future, referred to as the "contagion effect." There was presumably no fear that the market for municipal employees would be adversely affected, although this issue has been mentioned in some discussions of public pension reform.

You may wonder how the city could get away with treating one group of unsecured creditors better than another. Due to concern over the contagion effect, in the year before Central Falls filed its petition in bankruptcy, the Rhode Island legislature passed a statute granting general obligation bondholders a priority claim on city revenues, ${ }^{4}$ basically elevating their legal status to secured creditors or at least priority unsecured creditors, above claims of other unsecured creditors. From the point of view of the unsecured creditors left behind, this seems incredibly unfair, since it significantly reduced the funds available to pay the remaining unsecured claims. In effect, the legislation retroactively altered the priority among creditors, prejudicing some and privileging others. It could be viewed, in effect if not in law, as a fraudulent conveyance or illegal preference under which a substantial proportion of municipal revenue was placed beyond the reach of unsecured creditors, long after many of those creditors

\footnotetext{
${ }^{4}$ See R.I. Gen Laws $§ 45-12-1$ (2011).
} 
Beermann, Resolving the Public Pension "Crisis”, 11/11/2013

had extended credit to the municipality. However, Chapter 9 explicitly prohibits the bankruptcy court from interfering with the revenue and internal operation of the municipality, ${ }^{5}$ so perhaps state adjustments to priority like this should be respected by the bankruptcy court.

The legality of Rhode Island's strategy was never litigated in bankruptcy court. Rather, the entire process was subject to negotiation among the creditors. (In municipal bankruptcy, there is a statutory requirement of negotiation with creditors before filing.) Realizing that they were going to suffer serious reductions in their pension payments, the retired workers went along with the plan after they convinced the Rhode Island legislature to appropriate funds for a five year cushion during which the cuts to their pensions would be substantially less than the ultimate goal of 55 percent. In actuality, pension holders may have been treated better than the city's other unsecured creditors (excepting bondholders). Other unsecured creditors may have lost more than 55 per cent of the value of their claims. The city's other unsecured creditors apparently did not challenge what might have been viewed as relatively favorable treatment of pension recipients, perhaps because there wasn't really much money to fight over or because their interests were so devalued in municipal bankruptcy law.

The way this all occurred shows that municipal bankruptcy is a much more explicitly political animal than the typical bankruptcy of a private corporation. The state government engaged in long term planning for the Central Falls bankruptcy, first by securing the bondholders' claims to avoid the negative consequences to the rest of the bond market had

\footnotetext{
${ }^{5} 11$ U.S.C. $\S 904$. In fact, my colleague Walter Miller suggests in a recent article that even without this statutory provision, the increased flexibility built into Chapter 9 due to concerns over interference with government operations might allow municipalities to favor one group of unsecured creditors over another. See Walter W. Miller, Jr., Municipal Bonds in Chapter 9 Adjustment Proceedings, 9 Westlaw Journal Bankruptcy 3, 4 (2013).
} 
Beermann, Resolving the Public Pension “Crisis”, 11/11/2013

Central Falls defaulted and then by funding a cushion for pension claimants to convince them to agree to the plan. The gridlock endemic to the United States Congress makes it even more surprising to an outsider that the state legislature could act in such a nimble, well thought out fashion.

Municipal bankruptcy has several unique features - the bankruptcy court cannot appoint an outside trustee, the process cannot be converted into a liquidation, and the bankruptcy court is prohibited from taking steps that interfere with the exercise of the municipality's governmental powers. These special features of municipal bankruptcy are obviously connected with a feature of government not shared by private entities, namely the power to tax. When a municipal government decides to enter into bankruptcy, it is the product of a set of decisions by municipal and state policymakers to take a hammer to the municipality's financial difficulties. The municipality could increase taxes, cut expenditures or both and pay its debts. The state could provide subsidies, perhaps as part of a plan to reform municipal spending for the future. Of course, tax increases, spending cuts and state subsidies may be unpopular with taxpayers and may damage the municipality's ability to recover, but they are possible alternatives to bankruptcy. And a municipality could conceivably reach the limit of its ability to tax, especially when higher taxes and cuts to services drive taxpayers away. But the municipality and the state still have the power to take steps to pay debts that private entities, dependent on the market, do not.

In fact, Rhode Island's legislative effort to protect bondholders at the expense of other unsecured creditors illustrates the uneasy accommodation between Contract Clause principles and the federal bankruptcy power. Of course, the whole point of bankruptcy is to allow contracts 
Beermann, Resolving the Public Pension "Crisis”, 11/11/2013

to be broken. When an individual or a business is insolvent, it is not unjust for all creditors to share in the losses inherent in bankruptcy, in part because the bankruptcy process ensures that creditors are treated fairly according to the priority of their interests as recognized in state law. The fairness of bankruptcy is reduced or destroyed if debtors are allowed to pick and choose which creditors to favor and which to disfavor, which was apparently done in Rhode Island. However, municipalities have enormous power to manipulate their finances even without state help — they can issue new bonds and incur new obligations, which would dilute the value of preexisting unsecured claims. They are also not bound by the usual priority rules that apply in bankruptcy. But, when the debtor is a municipality, manipulation pursuant to the sovereign power of the state may be contrary to the spirit of the Contract Clause even if it is not contrary to the letter-it's as if the breach of contract was done pursuant to state law rather than federal bankruptcy law. ${ }^{6}$

Perhaps, however, the tables could be turned and manipulation could help pension claimants, especially in states in which government workers are still a politically favored class. If the Rhode Island legislature can retroactively secure bondholders' claims, presumably states could secure public pension claims and grant them priority over other unsecured municipal creditors. A state legislature could presumably act to protect pensioners by giving them a priority similar to the one granted to bondholders in Rhode Island. Many states have special constitutional or statutory provisions protecting public pension rights, such as the provision of

\footnotetext{
${ }^{6}$ This is why some bankruptcy courts and scholars of bankruptcy law have rejected the idea that States can establish priorities among creditors that are controlling in bankruptcy. See Martin J. Bienenstock \& Andrea G. Miller, Situational Update on Detroit's Chapter 9 Case: Michigan and Detroit's High Stakes Chapter 9 Constitutional Gambles 18 \& n. 45 (October 19, 2013) ("See County of Orange v. Merrill Lynch \& Co., Inc. (In re County of Orange), 191 B.R. 1005, 1017 (Bankr. C.D. Cal. 1996); 3 Collier on Bankruptcy 507.02 (15th ed. 1995) (“State legislatures cannot create bankruptcy priorities."))."
} 
Beermann, Resolving the Public Pension "Crisis”, 11/11/2013

the Michigan constitution which states "The accrued financial benefits of each pension plan and retirement system of the state and its political subdivisions shall be a contractual obligation thereof which shall not be diminished or impaired thereby." 7 The wording of this provision and others like it is designed in part to protect pension promises under the Contract Clause of the United States Constitution, which protects contractual promises but not the benefits of noncontractual regulatory programs. However, it is uncertain whether this language would be sufficient to create any special priority for pension promises under federal bankruptcy law. This has not been litigated although the Michigan Attorney General and pension claimants are doing so in the Detroit case.

The most interesting controversy to date over the interaction between state law protecting pension rights and federal bankruptcy law is occurring right now in Detroit. Michigan law allows municipal governments to pursue bankruptcy, but only with the permission of the Governor. $^{8}$ If an Emergency Manager has been appointed, as is the case in Detroit, then the Emergency Manager may pursue federal bankruptcy, but again only with the permission of the Governor and only after the Emergency Manager concludes that "no reasonable alternative to rectifying the financial emergency of the local government which is in receivership exists." 9 The political nature of these determinations is exemplified by the provision in Michigan law allowing the Governor to impose conditions on the bankruptcy filing. ${ }^{10}$

\footnotetext{
${ }^{7}$ Mich. Const. Art. IX, $\S 24$.

${ }^{8}$ M.C.L. 141.1566.

${ }^{9}$ M.C.L. 141.1558

${ }^{10} \mathrm{Id}$.
} 
Beermann, Resolving the Public Pension “Crisis", 11/11/2013

After the Emergency Manager for Detroit was appointed, there was a race to the courthouse between local employee interests on the one side and the Emergency Manager on the other. Employees and retirees were preparing to file suit in state court to enjoin the Governor and the Emergency Manager from taking any steps that would negatively affect their pension rights, while the Emergency Manager was preparing to file for federal bankruptcy protection, presumably to do just that. Detroit's bankruptcy petition was filed on July 18, 2013, one day before Michigan state court Judge Rosemarie Aquilina issued an "Order of Declaratory Judgment" finding that any effort to use federal bankruptcy to reduce public pension rights would violate the Michigan constitution. The judge ordered Michigan's Governor to direct Detroit's Emergency Manager to withdraw the bankruptcy petition and to not "authorize any further Chapter 9 filing which threatens to diminish or impair accrued pension benefits." The state court did not rule out a future Chapter 9 filing by Detroit, but implicitly urged the Governor to impose conditions on any such filing that would protect pension rights.

The trial court's order requiring the withdrawal of the bankruptcy petition has not been enforced. First, on July 23, 2013, the Michigan Court of Appeals ordered that Judge Aquilina's order be stayed pending appeal. Then, on July 24 , the federal bankruptcy court issued an order staying the state court proceedings, directing that the constitutionality of Detroit's bankruptcy filing be litigated in the federal bankruptcy court, along with other legal challenges to the propriety of Detroit's filing. The Michigan Attorney General has also appeared in the bankruptcy litigation, in part to represent the interests of pension holders. The Attorney General has apparently taken the position that the City cannot constitutionally use the bankruptcy to 
Beermann, Resolving the Public Pension “Crisis", 11/11/2013

reduce its pension obligations. This pits him in opposition to Michigan's Governor who has advocated pension reductions as part of Detroit's financial plan.

This potential conflict between the Michigan constitution and federal bankruptcy law is incredibly interesting. In part, the issue boils down to whether a state law authorizing a municipal government to file for federal bankruptcy protection can be found to be unconstitutional under the state constitution. (Let's put the jurisdictional conflict between the state court and the federal bankruptcy court to one side for now.) In my view, it seems clear that a state law authorizing municipal bankruptcy is subject to review under the state constitution. Suppose a state's constitution provided simply "Municipalities in this state may not file for bankruptcy protection under any federal or state law." Is there any reason to believe that the provision of the federal bankruptcy code requiring state permission for municipalities to use Chapter 9 overrides state constitutional provisions prohibiting it, somehow investing the state legislature with the power to ignore a provision of the state constitution? This would be contrary to the well-established understanding that municipal governments are creatures of the state and completely subject to control by state law, and that municipalities have only those powers granted to them under state law. If anything, the fact that municipalities need state permission to file for bankruptcy should be viewed as enhancing state law as a limitation on municipal bankruptcy, and the state constitution, as the supreme law of the state, should prevail over any statute determined by the state's judicial branch to be in conflict with the state constitution.

A decision that the Michigan constitution prohibits the state's municipalities from reducing their pension obligations in federal bankruptcy would not amount to a denial of the 
supremacy of federal law or be in the nature of state nullification of federal law. ${ }^{11}$ Rather, this would be an example of the sort of cooperative federalism that has become increasingly common, under which federal law is optional. Spending Clause regulation is the most common of these-states do not violate federal law if they refuse to expand Medicaid eligibility under the Affordable Care Act or if they refuse to establish 21 as the minimum age for purchasing alcoholic beverages. Rather, they simply forgo whatever federal benefits are attached to the rejected strings. It would not violate federal law for a state's supreme court to declare that eighteen year olds have a constitutional right to drink beer and wine, even if the court's decision prevented a state from raising the age to 21 to take advantage of federal highway construction subsidies.

The jurisdictional conflict between the Michigan state court and the federal bankruptcy court may create procedural complications, but it should not alter the substantive outcome. Bankruptcy filings normally stay other state and federal court proceedings involving the debtor, ${ }^{12}$ but ultimately state law will govern the resolution of many of those cases. If a Michigan court issues an authoritative decision holding that it violates Michigan law for any Michigan or Detroit official to use federal bankruptcy to diminish retiree benefits, the federal bankruptcy court would have three options: It could decide that Detroit is ineligible to use Chapter 9, it could live with the state court's decision and adjust all debts other than those covered by Michigan law, or it could ignore Michigan law and make adjustments to retiree

\footnotetext{
${ }^{11}$ Cf. Frederick Tung, After Orange County: Reforming California Municipal Bankruptcy Law, 53 Hastings L.J. 885,887 (2002) ("The federal requirement of state authorization derives from the Constitutional principle that the federal government may not interfere with states' internal governance.”)

${ }^{12}$ The Bankruptcy Code's automatic stay provisions apply in Chapter 9 cases. See 11 U.S.C. § 901(a) (2006).
} 
Beermann, Resolving the Public Pension “Crisis”, 11/11/2013

benefits in disregard of the Michigan constitution. The bankruptcy court in the Orange County California bankruptcy appears to have rejected the second option, finding that " $[\mathrm{b}] \mathrm{y}$ authorizing the use of chapter 9 by its municipalities, California must accept chapter 9 in its totality; it cannot cherry pick what it likes while disregarding the rest. The right to discharge is not a benefit without burdens." ${ }^{\prime 13}$ If the bankruptcy court cannot live with the selective adjustment of Detroit's debts pursuant to Michigan law, it should find Detroit ineligible for Chapter 9 rather than go ahead with the adjustment in disregard of Michigan's protection of pension rights.

In my view, the federal bankruptcy court should be bound by Michigan law on the question whether the municipality is authorized to use Chapter 9 either generally or in a way that would prejudice pension claimants. Given that this is a novel and difficult issue of Michigan law, any determination the bankruptcy court or any other federal court would make would only be a prediction, and may be proven incorrect. Thus, whatever procedure the bankruptcy court uses to decide whether the bankruptcy filing violates the Michigan constitution should allow the Michigan courts to have final say on that issue. Had the Supreme Court of Michigan invalidated the Michigan statute authorizing municipal bankruptcy before any Michigan municipality had filed, perhaps on a facial challenge shortly after the law was passed, the federal bankruptcy court would not be free to ignore that decision and allow Michigan's municipalities for file for bankruptcy anyway.

The interaction between the Contract Clause and federal bankruptcy might seem to be in tension with the possibility that state constitutional protections of pension rights limit the ability of municipal governments to use Chapter 9 to reduce those rights. Although Contract Clause

${ }^{13}$ In re County of Orange, 191 B.R. 1005, 1021 (Bkrtcy.C.D. Cal. 1996). 
Beermann, Resolving the Public Pension "Crisis”, 11/11/2013

doctrine is flexible and has been found to allow significant pension reform, ${ }^{14}$ the clause does place limits on the ability of state and local governments to adjust their pension liabilities.

Constitutional provisions protecting pension rights like Michigan's are drafted with the Contract Clause in mind, because they clearly meet one of the requirements for Contract Clause protection, that the state or local promise be contractual in nature. The Contract Clause, by its terms, applies only to states, which is why federal municipal bankruptcy is possible. If the state itself simply reduced pension payments as part of a state-run reform of municipal finances, there is a good possibility that a court would find a violation of the Contract Clause. Because federal law is not subject to the Contract Clause, a bankruptcy court judgment reducing state or local pension payments raises no similar issue. ${ }^{15}$

The question is whether the fact that federal bankruptcy law can overcome Contract Clause protections based on state contractual commitments means that federal bankruptcy law should also overcome state constitutional limits of municipal power to employ federal bankruptcy. While this is a novel legal question, I don't think there is very much to it. I see the analogy, but the key difference is that in the Contract Clause case, the purported conflict is between two aspects of federal law, the Contract Clause and Chapter 9 of the Bankruptcy Code, and the Contract Clause simply does not apply to federal law. State constitutional limits apply to all state action regardless of federal law. In extreme cases, for example when state constitutional

\footnotetext{
${ }^{14}$ See, e.g., Parker v. Wakelin, 123 F.3d 1 ( $1^{\text {st }}$ Cir. 1997).

15 The first federal municipal bankruptcy law was invalidated by the Supreme Court in part on Contract Clause grounds. See Ashton v. Cameron Cnty. Water Improvement Dist., 298 U.S. 513 (1936). A later federal municipal bankruptcy law was upheld, See United States v. Bekins, 304 U.S. 27 (1938), and it is no longer thought that the Contract Clause limits the federal bankruptcy power.
} 
Beermann, Resolving the Public Pension "Crisis”, 11/11/2013

law invidiously discriminates, ${ }^{16}$ federal constitutional law might have something to say about state constitutional limitations on state governmental power, but there is no similar reason to denigrate state constitutional protection of pension rights.

In fact, there are reasons to believe that Congress intended to preserve state and local authority over municipal bankruptcy. As noted, municipalities need state permission to file under Chapter 9. Further, several additional provisions of Chapter 9 recognize the special status of states and municipalities. Municipal bankruptcy cannot be involuntary-the municipality must choose to use Chapter 9 to deal with its financial difficulties. ${ }^{17}$ Further, Chapter 9 prohibits the bankruptcy court from interfering with the municipality's governmental and political powers without the municipality's consent, ${ }^{18}$ and there is no provision for liquidation of a municipality by the federal bankruptcy court. ${ }^{19}$ Chapter 9 also conditions the approval of the plan for adjustment on a finding that "the debtor is not prohibited by law from taking any action necessary to carry out the plan." 20 In short, numerous provisions of the federal municipal bankruptcy law recognize that federal law should interfere as little as possible with the structure and operation of local governments in the federal bankruptcy process.

In sum, for better or for worse, many states have enacted special constitutional and statutory protections for state and local pension participants. Although these state provisions

\footnotetext{
${ }^{16}$ See Romer v. Evans, 517 U.S. 620 (1996) (striking down Colorado constitutional provision, passed by referendum, prohibiting the state and local governments from protecting homosexuals from discrimination).

${ }^{17}$ See 11 U.S.C. $\S 109(\mathrm{c})(4)(2006)$.

${ }^{18} 11$ U.S.C. $\S 904$ (2006).

${ }^{19}$ See David A. Skeel, Jr., States of Bankruptcy, 79 U. Chi. L. Rev. 677, 693 n.70 (2012).

${ }^{20} 11$ U.S.C. $\S 943(\mathrm{~b})(4)$. The Attorney General of Michigan is apparently arguing that this provision, in conjunction with the Michigan constitution's pension protection clause, prohibits reduction of Detroit's pension obligations in bankrupcty. The argument is that Michigan law prohibits any reduction in pension benefits so under $\S 943(\mathrm{~b})(4)$ the bankruptcy court may not order any reduction. It remains to be seen whether this is a correct interpretation of this provision of Chapter 9.
} 
Beermann, Resolving the Public Pension "Crisis”, 11/11/2013

might not grant priority to pension obligations that would be recognized by a federal bankruptcy court, they may limit the authority of state officials to use bankruptcy to reduce local pension obligations. Federal bankruptcy courts should respect state court decisions finding that, under state constitutional law, state and local officials may not employ federal bankruptcy to reduce pension obligations to current or retired municipal workers.

There are at least two more cases in the federal courts challenging changes to the retirement benefits of Michigan municipal employees, but neither case has addressed the issue of whether reductions in retiree benefits violate the Michigan constitution's pension protection provision. In one case, an Emergency Manager appointed under Michigan law to address the City of Flint's financial difficulties unilaterally changed city retirees' health care benefits, making their health insurance more expensive. The federal district court issued a temporary restraining order against the alterations, finding that the plaintiffs were likely to succeed on their claim that the changes violated the federal Contracts Clause. ${ }^{21}$ In the other case, after the Emergency Manager appointed to deal with the finances of the City of Pontiac altered Pontiac retirees' health benefits, a different federal district judge refused to issue a temporary restraining order, finding that even if the plaintiffs were likely to succeed on their claims that the changes violated the Contract Clause, they had not established that they would suffer irreparable harm if the changes were allowed to go into effect and then were reversed later when the merits of the lawsuit are reached. ${ }^{22}$ This latter decision was reversed by the Court of Appeals for the Sixth Circuit on the ground that, under the doctrine of constitutional avoidance, the federal court

\footnotetext{
${ }^{21}$ Welch v. Brown, 935 F. Supp.2d 875 (E.D. Mich. 2013).

${ }^{22}$ City of Pontiac Retired Employees Ass'n v. Schimmel, 2012 WL 2532763 (E.D. Mich. 2012), rev'd 726 F.3d 767 $\left(6^{\text {th }}\right.$ Cir. 2013).
} 
Beermann, Resolving the Public Pension "Crisis”, 11/11/2013

should have first addressed whether possible procedural defects in the Michigan legislature's passage of the statute authorizing the Emergency Manager to act violated the Michigan constitution, thus potentially mooting the federal constitutional claims. ${ }^{23}$ Interestingly, a dissenter would have reached the merits of the federal constitutional claims and would have rejected them, in part on the ground that "the EM's [Emergency Manager's] efforts to address the City of Pontiac's impending insolvency serve a legitimate public purpose" satisfying the requirements of the federal Contract Clause. ${ }^{24}$

There is also an interesting dispute over pension reform in Illinois. The Illinois Constitution contains a provision protecting public pension rights similar to the one found in the Michigan Constitution: "Membership in any pension or retirement system of the State, any unit of local government or school district, or any agency or instrumentality thereof, shall be an enforceable contractual relationship, the benefits of which shall not be diminished or impaired." 25 Public pensions in Illinois may be in worse financial condition than any other state's. They are certainly terribly underfunded. ${ }^{26}$ Although there has been some recent talk about Chicago following Detroit into bankruptcy, it is unclear whether municipalities in Illinois can actually use federal bankruptcy. Some have tried and their petitions have been dismissed. ${ }^{27}$

${ }^{23}$ City of Pontiac Retired Employees Ass'n v. Schimmel, 726 F.3d 767 (6 ${ }^{\text {th }}$ Cir. 2013).

${ }^{24}$ Id. at 786 (Griffin, J., dissenting).

25 Ill. Const. Art. XIII, $\S 5$.

${ }^{26}$ See ILLINOIS GENERAL ASSEMBLY, REPORT OF THE PENSION MODERNIZATION TASK FORCE 10 (2009) (available at http://cgfa.ilga.gov/upload/112009pensiontaskforcereport.pdf) (showing more than $\$ 61$ billion in state pension underfunding as of 2009). More recently, Crain's Chicago Business has estimated the shortfall to be more than \$100 billion. See Paul Merrion, Illinois Hits a Sorry Milestone, Crain's Chicago Business (March 25, 2013).

${ }^{27}$ See In re Slocum Lake Drainage District of Lake County, 336 B.R. 387 (N.D. Ill. 2006); Judge denies Washington Park's bankruptcy bid, AP Story, January 11, 2011, available at http://www.stltoday.com/news/local/illinois/judgedenies-washington-park-s-bankruptcy-bid/article_9db5faee-7ab1-5d6d-b29c-0938a11f7a00.html (Village of Washington Park, Illinois, found to have no authority to file Chapter 9 bankruptcy petition.) 
Beermann, Resolving the Public Pension "Crisis”, 11/11/2013

There is no general provision in Illinois law allowing municipalities to file for federal bankruptcy protection, only a provision that, after a fiscal emergency has been declared, a commission established by the Governor may "recommend that the unit of local government file a petition under Chapter 9 of the United States Bankruptcy Code."28 The statute does not specify who is to receive this recommendation and it does not authorize any entity to actually file a petition.

At the state level, there has been pressure for reform to state pensions from the business community. Everyone agrees that Illinois pension systems are grossly underfunded and that the underfunding has resulted in large part from state legislature's failure to make actuarially adequate contributions to the funds. In some years, pension obligation bonds were issued and even some of the proceeds of those bonds were diverted to other purposes in the state budget. However, the Illinois General Assembly has been unwilling to pass significant reforms.

The Illinois General Assembly formed a task force that in 2009 issued a report on pension funding problems. ${ }^{29}$ The Civic Committee of The Commercial Club of Chicago, an organization of business leaders formed in the late nineteenth century, issued a minority report recommending cuts to benefits already earned by existing employees and perhaps increased employee contributions. The Commercial Club also placed some of the blame for underfunding on overly generous benefits and abuses such as working two state jobs to earn two pensions. Although the scope of its recommendations is somewhat unclear, The Commercial Club's report apparently relied on a legal analysis of Illinois public pension law conducted by the law firm of the club's president. In response, the Chief Legal Counsel to the Illinois Senate President wrote

\footnotetext{
${ }^{28} 50$ Ill. Comp. Stats. Ch. 320 § 9(b)(4).

${ }^{29}$ ILLINOIS GENERAL ASSEMBLY, REPORT OF THE PENSION MODERNIZATION TASK FORCE (2009).
} 
Beermann, Resolving the Public Pension "Crisis”, 11/11/2013

a lengthy article, the last 30 pages of which are a rebuttal of the legal analysis underlying The Commercial Club's report. ${ }^{30}$ The article concludes that Illinois law does not allow any reduction in promised future benefits to current employees and it also prohibits requiring increased employee contributions for the same level of benefits. Although the article's conclusions are supported by Illinois caselaw, it remains to be seen what, if anything, the Illinois General Assembly does about the problem and whether the Illinois courts uphold any reforms ultimately enacted.

The latest chapter in the Illinois pension saga is that the Governor, an advocate of pension reform, vetoed the line in this fiscal year's state budget providing pay for legislators, stating that legislators should not be paid until they enact pension reform. The Governor also voluntarily refused his salary during the controversy. The legislators responded by filing suit against the Governor, claiming that the Governor's veto violated the Illinois Constitution, and so far, the trial court has found in favor of the legislators and ordered their pay restored. ${ }^{31}$ It remains to be seen whether this ruling is upheld if and when the Governor appeals.

II.

It seems clear that in many state and local governments, pension reform is coming. In some locales, retirees are likely to see increased health care costs and even reduced pension payments, whether through municipal bankruptcy, fiscal emergency management or state legislation. For future employees, reform may take the form of reduced promises and perhaps a

\footnotetext{
${ }^{30}$ See Eric M. Madiar, Is Welching on Public Pensions an Option for Illinois? An Analysis of Article XIII, Section 5 of the Illinois Constitution 44-74 (Mar. 1, 2012), available at http://papers.ssrn.com/sol3/papers.cfm?abstract_id=1774163.

${ }^{31}$ See Cullerton v. Quinn, No 13 CH 17291, Memorandum Opinion and Order (Sep. 26, 2013) (veto of legislative salaries violated Ill. Const. Art. IV, § 11, which prohibits changes to the salary of Members of the Illinois General Assembly in the middle of a term).
} 
shift away from defined benefit plans to defined contribution plans, ${ }^{32}$ and a move to have workers take advantage of federal Medicare rather than maintain the entitlement that exists in some places to lifetime private insurance coverage. In recent months, we have seen this last shift in the private sector, with large corporations closing their retiree health care plans and substituting cash payments to retirees, with which they are supposed to purchase their own insurance on the market.

One view of public pension reform is that it should be understood in the context of the national labor market and the negative political atmosphere surrounding the status of public employees. Union membership is at an extremely low level in the private workforce, while it remains relatively strong in public employment. In the private sector, good jobs with benefits for relatively low skilled workers have become increasingly difficult to come by. In the retail and fast food sectors, employers have taken advantage of the weak job market by maintaining a largely part-time work force, paying low wages without benefits and not providing workers with regular schedules, which makes it difficult for them to earn a living by working at multiple jobs. It has even been reported that some fast food employers provide counseling to full-time employees on how to qualify for government benefits such as food stamps. Even in traditionally high-wage lower-skilled occupations, more recently hired workers are paid less and have lower benefits than long-time employees who began their employment when unions were still relatively strong. Income inequality in the United States is at an all-time high and is still

\footnotetext{
${ }^{32}$ As Professor Paul Secunda pointed out at the conference for which this essay was prepared, defined contribution plans have problems of their own, mainly due to faulty design. According to Professor Secunda, many employees in voluntary defined contribution plans tend not to save enough and do not have adequate information or knowledge to direct their investments. These problems could easily be resolved through better plan design.
} 
Beermann, Resolving the Public Pension "Crisis”, 11/11/2013

growing. ${ }^{33}$ Despite recent strikes by low wage fast food workers, the balance of power at the low end of the wage scale is tilted strongly on the side of employers.

In my earlier article on the public pension crisis, I showed that whether public employees are overcompensated is a hotly contested issue. While some of the research indicates that public employees are overcompensated as compared to the private sector, other research indicates that after controlling for age, education and experience, public sector employees are somewhat underpaid. An element of the supposed overcompensation of public employees is that they are alleged to be entitled to overly generous pensions and post-retirement health care benefits. In response, one fact that is often touted by those claiming that public employee retirement benefits are not unreasonable is that the average public employee pension is something close to $\$ 20,000$, and many public employees did not pay into the federal Social Security system, so they do not receive those benefits. However, it is not always known how much service it took for retirees to earn that $\$ 20,000$ pension $^{34}$ and thus it is not a very useful metric for making an informed judgment about the situation of pension claimants.

It is not clear how long the generally favorable conditions in public employment, as compared to the private sector, will last. Public sector collective bargaining was the focal point in 2011 in Wisconsin, when the newly-elected Governor and the state legislature moved to

\footnotetext{
${ }^{33}$ See Emmanuel Saez, Striking it Richer: The Evolution of Top Incomes in the United States (Updated with 2012 preliminary estimates), September 3, 2013, available at http://elsa.berkeley.edu/ saez/saezUStopincomes-2012.pdf.

${ }^{34}$ According to a recent report by the Auditor General and Inspector General of Michigan, in Detroit, an employee retiring after 25 years at a final salary of $\$ 46,000$ per year would earn a lifetime pension of approximately $\$ 20,000$ per year, as would an employee retiring after 30 years at a final salary of $\$ 36,000$, an employee retiring after 35 years at a final salary of $\$ 30,000$ and an employee retiring after 40 years at a salary of $\$ 26,000$. See Report of the Auditor General \& Inspector General in response to Emergency Manager Order No. 8 at 6 (table) (July 1, 2011March 31, 2013) available at http://www.detroitmi.gov/Portals/0/docs/EM/Reports/EMO8\%20FINAL\%20REPORT\%20Sept\%2026\%202013.pdf
} 
Beermann, Resolving the Public Pension “Crisis”, 11/11/2013

eliminate the right of most public employees in the state to collective bargaining over anything but wages. Employees' required health care and pension contributions were also increased at the same time. While teachers' unions have long been blamed by some for the problems of the public schools, the pension crisis has focused attention on the compensation and benefits of all state and local employees. Public employees have been portrayed as overpaid both in terms of current compensation and especially with regard to retirement benefits, including pensions and health care. Although the predominant cause of the public pension crisis seems to be the fiscal irresponsibility of state legislatures, the recent focus on state and local pensions and retiree health care benefits may be softening the public up for acceptance of major reforms that would significantly reduce benefits.

Although the changes in Wisconsin did not spark an immediate nationwide effort to restrict or eliminate public employee collective bargaining, it would not be surprising if pension reformers target public employee unions. Perhaps the most telling attack on public employee unions is Daniel DiSalvo's 2010 article in National Affairs, "The Trouble with Public Sector Unions." 35 Whether you agree with it or not, the article is thoughtful and thought provoking, and lays much of the blame for state and local fiscal problems at the feet of public employee unions. ${ }^{36}$ With regard to pensions, Disalvo explains that:

\footnotetext{
${ }^{35}$ See Daniel Disalvo, The Trouble with Public Sector Unions, National Affairs 3 (Fall, 2010).

${ }^{36}$ I do not agree with Disalvo's conclusions concerning the negative effects of public sector unions. In my view, Disalvo's analysis lacks context. I assume he is correct that unionization has resulted in better pay, benefits and working conditions for public employees. That is the whole point of collective action by labor. The question I am left with is what situation would we be in without public employee unions? Would things be much better, or would business lobbying divert an even greater share of public resources to business interests at the expense of the taxpaying public and government workers? In my view, there is a significant chance that many social problems such as climate change, environmental pollution, dangerous work places, income inequality, poor public education and tax inequity would be worse without the voice of organized labor in the political mix.
} 
Beermann, Resolving the Public Pension “Crisis", 11/11/2013

$[\mathrm{M}]$ any lawmakers found that increasing pensions was very good politics. They placated unions with future pension commitments, and then turned around, borrowed the money appropriated for the pensions, and spent it paying for public services in the here and now. Politicians like this scheme because they could satisfy the unions, provide generous public services without raising taxes to pay for them, and even sometimes get around balanced-budget requirements. ${ }^{37}$

My only quibble with Disalvo's analysis here is that he omits mention of the fact that often underfunding resulted from the failure to actually appropriate funds for the pensions, which led to the severe underfunding we see in so many state and local governments.

Disalvo recognizes that more than government finances and policymaking are at stake in efforts to reform public sector labor relations. He sees very clearly the connection between collective bargaining and the status of lower-skilled workers. As he portrays it, "In today's public-sector, good pay, generous benefits and job security make possible a stable middle class existence for nearly everyone from janitors to jailors. In the private economy, meanwhile, cutthroat competition, increased income inequality, and layoffs squeeze the middle class." The subtext here is that just as consumers and shareholders benefit from low wages in the private sector, which keep many workers from earning a living wage, so too should taxpayers be able to take advantage of the competitive labor market to reduce government expenses, even if that drives another group of workers out of the middle class. There is something even larger than the fight over public pension rights underlying this discussion. It's about whether the United States

\footnotetext{
${ }^{37}$ Id. at 15 .
} 
Beermann, Resolving the Public Pension “Crisis”, 11/11/2013

economy will support a thriving middle class or whether it will join the many countries in the world that are divided between rich and poor.

Millions of people have trillions of dollars at stake in their pension and retiree health care benefits, and many state and local governments across the United States are in a fiscal squeeze. Should these state and local governments solve their fiscal problems at the expense of their employees, retired and active? Strict insistence that municipal governments live up to every promise they have made to all retirees and employees may cripple their ability to recover from the financial crisis or provide the level of services taxpayers demand (often without willingness to pay enough in taxes to fund them). Politically, placing the burden on employees is likely to be more palatable than placing it on taxpayers. However, the employees and retirees involved have strong normative claims that they should not bear the brunt of the reforms necessary to resolve governmental fiscal problems. The question is, who should?

Employee retirement benefits, including pensions and health care benefits, should be protected from significant reduction both within and outside of municipal bankruptcy. These benefits were earned over time, often in exchange for reduced current compensation and lesser opportunities for advancement. The average current or retired government employee is not to blame in any realistic sense of the word for the fiscal predicament of state and local governments, unless you accept Disalvo's conclusion that government's problems stem in large part from an unholy alliance between politicians and public employee unions. In my earlier article, I acknowledged that public employees may sometimes receive favorable treatment due to the expectation that they will support incumbent politicians, but most government employees have little if any direct involvement with political officials such that their pay and benefits 
Beermann, Resolving the Public Pension "Crisis”, 11/11/2013

should be viewed as more political than compensation for services provided. The primary pathology that led to the underfunding of public pensions is the political desire to provide more services to the public than the public is willing to pay for in current taxation. At the federal level, this is done by running deficits, currently amounting to more than $\$ 16$ trillion. At the state and local level, this has been accomplished in part by underfunding retirement benefits to government employees, which means that current taxpayers are not paying the full costs of the services and programs they enjoy every day. The primary target for resolving state and local financial problems should be the taxpayers, not current and former employees.

For several reasons, Detroit may be a special case. Many of the taxpayers of Detroit are in a worse predicament than current or retired workers. Property values in Detroit have plummeted, unemployment has skyrocketed, and many public services have virtually disappeared. Meanwhile, there are suggestions of fraud and other abuses in the Detroit pension system. ${ }^{38}$ By contrast with Central Falls, bondholders in Detroit are unlikely to be paid in full. ${ }^{39}$ If significant cuts are made to Detroit pension and retiree health care payments, the cuts should be based on Detroit's special circumstances and not on a general model of municipal debt adjustment or bankruptcy that would provide a national precedent for cuts to pension and other retiree benefits.

Significant cuts to state and local pensions would likely place large numbers of older Americans at risk of falling into poverty, especially those who did not participate in the federal

\footnotetext{
${ }^{38}$ See Report of the Auditor General and Inspector General, supra note x, at 7-9.

${ }^{39}$ For an interesting discussion of the plight of bondholders with investments in municipalities with financial problems, see Clayton P. Gillette, Bondholders and Financially Stressed Municipalities, 39 Fordham Urb. L.J. 639 (2012). Gillette highlights the uncertainty concerning priorities in municipal bankruptcy. See id. at 646-47 \& n. 55.
} 
Beermann, Resolving the Public Pension "Crisis”, 11/11/2013

Social Security program. In recent decades, there have been bailouts and compensation funds established when disaster strikes. As I noted in my prior article on the public pension crisis, the website propublica.com reported that 928 institutions received more than $\$ 600$ billion in federal bailout funds during the recent financial crisis, including nearly $\$ 200$ billion to Fannie Mae and Freddie Mac, and nearly $\$ 70$ billion to the insurance company AIG. ${ }^{40}$ In the late 1980 s and early 1990s, there was an enormous government bailout of the savings and loan industry. When natural disasters strike, government provides significant aid to victims. How should society treat those likely to be thrown into poverty if their state or local pension is significantly cut?

Throwing a large number of elderly Americans into poverty would cause a major national public policy problem. The federally-funded health care system would likely become responsible for billions of dollars in health care costs to the newly impoverished. Perhaps what the situation calls for is an ambitious plan administered the way Kenneth Feinberg has administered funds like the 9/11 fund and the fund set up by BP Oil Co. to compensate victims of the 2010 oil spill in the Gulf of Mexico or the way that Trustee Irving Picard has distributed the assets available after the discovery of Bernard Madoff's Ponzi scheme.

The central normative question is whether pension claimants should be treated more like the innocent victims of a financial disaster or like the investors in Bernard Madoff's Ponzi scheme. In a disaster, whether it be a natural disaster or a terrorist strike or an industrial accident, outside funding is used to ameliorate the financial consequences that would otherwise occur. In the Madoff case, investors were paid only out of the funds that the trustee could

\footnotetext{
${ }^{40}$ Bailout Recipients, ProPublica.com (Oct. 12, 2012), http://projects.propublica.org/bailout/list (last visited Oct. 24,
} 2012). 
Beermann, Resolving the Public Pension “Crisis”, 11/11/2013

recover either in Madoff's assets or clawbacks from investors who had received distributions from Madoff in excess of what they had invested.

Under the most uncharitable view of their situation, public pension claimants could be portrayed as in a similar situation to Madoff's investors. Just as Madoff led his investors to believe that their accounts were worth much more than was actually there, pension claimants have been misled by government into believing that their employer or former employer has or will have sufficient funds to pay the full retirement benefits promised. Just like Madoff's investors, they should have realized that the promises were unrealistic, but their greed blinded them to what should have been obvious. Pension claimants are even more to blame than Madoff's investors, because they bargained for the excessive and unrealistic promises that are weighing government down. Under this characterization, the most pension claimants should be entitled to is a proportionate share of the assets actually available to pay their claims, which in some state and local governments may be fifty cents on the dollar or even less.

For many reasons, I do not believe that it would be fair or practical to treat pension claimants like the investors in Bernard Madoff's Ponzi scheme. On practicality first, in many situations, it would be very difficult to identify the assets that pension claimants would share. Few government pension programs are fully funded, and it was always anticipated that funds might be augmented by current appropriations to make sure that all payments can be made. It might also be impossible to segregate the funds that have been appropriated into the various pension programs that may be underfunded to a greater or lesser degree. Perhaps the necessary accounting would be possible for pension funds that are help in trusts separate from other government finances, but it would be very difficult when separate accounts are not maintained. 
Beermann, Resolving the Public Pension “Crisis”, 11/11/2013

The argument against this sort of treatment is stronger from a fairness perspective. Unlike Bernard Madoff's investors, pension claimants were promised their pension payments in exchange for services performed, not merely as passive investors in a financial scheme. The governmental unit received decades of service from the people whose pensions are now at risk. Further, for each state or municipal pension system, except perhaps in a few extreme cases, the magnitude of the promises, while generous, were not so out of line with other governmental pensions that employees should have been on notice that their expectations were unreasonable. Along the same lines, the typical government worker was not complicit in creating the pension mess in any meaningful sense. Government workers would have preferred that their pensions be fully or close to fully funded, and they did not join in any sort of overt scheme to procure excessive payments. In some cases, state governments failed to appropriate sufficient funds to make actuarially required pension contributions while at the same time cutting state taxes. Also, government workers cannot easily diversify the risk of non-payment of pensions the way smart investors can diversify the risk of poor performance or fraud in their investments. Of course workers can choose private employment or a public position with a defined contribution pension plan, but employment is nowhere near as mobile as money in terms of saving for retirement.

Should government pension claimants be thought of as innocent victims of a fiscal disaster who should be bailed out the way the government bailed out significant elements of the financial industry after the 2008 financial crisis or the way government created a fund to compensate families for the loss of life in the 2001 terrorist attacks? In my view, pension claimants are closer to this characterization than to the blameworthy characterization described above. The average government employee did not engage in any improper practice that led to 
Beermann, Resolving the Public Pension “Crisis”, 11/11/2013

excessive pension promises. Of course, if you believe that unions are the devil in all of this, then union membership and enjoyment of the fruits of collective bargaining is enough to cast blame on even the lowliest government employee. But for most government employees, a day's work earned a day's pay, and pension promises were simply part of the compensation that was promised. Workers had no more control than the average taxpayer over how much was set aside each year to meet future retirement obligations, and taxpayers enjoyed the benefits of the government services provided by the employees without paying their full, current, cost.

Perhaps comparing pension claimants to victims of other disasters would be helpful. Although in the abstract it might be tempting to place blame for losses on people who choose to live or establish businesses in tornado prone areas or along earthquake fault lines, in general we do not withhold disaster relief from such people. In flood zones, the federal government offers flood insurance, and once premiums are paid, we don't question the entitlement to benefits because the victims chose to live in a flood zone. Pension claimants, having worked for their pension rights, are in a similar position to property owners who have paid flood insurance premiums and find it necessary to file a claim. The lobbying and bargaining that pension claimants may engage in should not disqualify them from consideration any more than the political process that leads to disaster relief, or other favorable treatment, should disqualify those recipients. All government action stems from some level of bargaining and lobbying. In my view, departure from the principal of full payment of pension promises is justified only if, pursuant to an appropriate process, it becomes clear that some aspect of promised benefits is abusive and unrelated to the legitimate purposes of a pension system. The core pension benefit based on some measure of the recipient's final pay should be preserved. This 
Beermann, Resolving the Public Pension “Crisis”, 11/11/2013

principle does not rule out reforms aimed at cutting potentially abusive practices that allow for what is known as pension "spiking." Some jurisdictions, for example, no longer allow longevity pay to be included in pension calculations, especially the sort of longevity pay that is awarded on notice of retirement simply to increase pension payments. It would not be contrary to this principle to disallow the inclusion of second jobs in pension calculations, so for example, public school teachers cannot increase their pensions by teaching at community colleges during their last few years when pension benefits are calculated. Accounting errors and abuses should also be correctable. Non-salary benefits, such as housing or transportation allowances, might also be appropriately eliminated from pension calculations. Overtime may also be properly excluded from pension calculations in most circumstances, although for some government employment in which overtime is routine and expected as part of the position, it might be appropriate to include it. If employees make contributions to pension funds based on their overtime, then they ought to receive benefits accordingly.

The issue becomes more difficult when highly paid government employees retire with pensions that appear exorbitant. Should the chancellor of a state university system receive a lifetime pension of more than $\$ 200,000$ per year based on a final salary of approximately $\$ 300,000$, or should there be a maximum pension cap established? Does it matter that officials of private organizations of similar size and complexity often receive even more in pay and retirement benefits? It may be fair to pay the full pension since the leader of a state university system may have declined or failed to pursue private opportunities in reliance on the pay and benefits package promised by the state. High salary and pension promises are not reason alone for failure to pay. 
Beermann, Resolving the Public Pension "Crisis”, 11/11/2013

Assuming that cuts to some pension payments are inevitable, what is needed in each state is a comprehensive review of the pension system under clear guidelines established in a process that includes input from all affected parties. The leader of the process should act with intellect, political sensitivity and compassion, as the administrators of other compensation and relief funds have done in recent years. Of course, ultimately judges and politicians will make the decisions about whether cuts will occur and of what magnitude. In some states, in reliance on state constitutional protections of public pension rights and Contract Clause principles, the courts may refuse to allow any cuts, and if municipal bankruptcy is not authorized, state and local workers in these states may be fully protected. According to one analysis, the Bankruptcy Code itself should be understood to place serious limits discharge of pension liabilities by cities such as Detroit. $^{41}$ The claim here is that Code $\S$ 943(b)(7)'s requirement that municipal bankruptcy plans be "in the best interests of creditors" means that "creditors are entitled to Detroit's going concern value, not its liquidation value." The legislative history cited in support of this claim indicates that this provision "is intended to provide more of a return to creditors than the liquidation value" and should "allow the municipal unit to continue operating while it adjusts or refinances creditor claims with minimum (and in many cases, no) loss to creditors."42

In my view, if cuts are to be made, care should be taken to preserve the core of a pension that meets the legitimate expectations of workers. To me, for instance, the 55 percent cut imposed on Central Falls, Rhode Island, retirees was too harsh, and if a municipality lacks the funds to pay enough to maintain a sufficient pension system, the state should be forced

\footnotetext{
${ }^{41}$ See Bienenstock \& Miller, supra note $\mathrm{x}$ at 21-24.

${ }^{42}$ See id. at 22, quoting Senate Report No. 95-989, 95th Cong., 2d Sess. (1978) at 113, 263.
} 
Beermann, Resolving the Public Pension "Crisis”, 11/11/2013

appropriate funds to make up the difference. To reduce a promised pension from $\$ 25,000$ annually to $\$ 11,250$, especially for a person who did not pay into federal social security, is cruel, and the law should not allow this to happen, whether inside bankruptcy or out. Entities with the power to tax should not be allowed to treat their employees that way.

Retiree health care presents a more difficult problem because of the enormous cost increases that have occurred in recent years. Many government employees are promised lifetime health care at little or no cost to them, and few if any governmental units set aside money in advance to fund this obligation. It is unlikely that anyone anticipated the magnitude of recent increases in health care costs. In pure contract law terms, the magnitude of the unanticipated cost increases may provide a defense to the charge of breach of contract if a government employer forced retirees to contribute more to health care costs than had been agreed or promised. It does not seem to me to be unfair to ask retired employees to modestly increase their contribution to their health care costs in an environment in which everyone is paying substantially more. The increase, or any cut to benefits, should not be so large that it imposes serious hardship on retirees, but just as Medicare costs increase over time, it is reasonable to expect state and local retirees to contribute more to their health care in an era of skyrocketing costs.

III.

The Detroit bankruptcy filing highlights how underfunded pension promises are contributing to financial distress for municipalities and states across the United States. Before municipal bankruptcy becomes the accepted, if not routine, means employed by distressed cities and towns to restructure and reduce their pension obligations, a great deal of thought should be 
Beermann, Resolving the Public Pension "Crisis", 11/11/2013

given to the plight of current and retired workers who are counting on their pensions for economic security late in life. Employees and retirees cannot diversify their risk the way that investors and most other creditors can. They cannot retroactively participate in the federal Social Security system or easily change careers after they discover that their pensions are insecure. In general, state and local governments should live up to the pension promises they made to their employees, subject to reasonable reforms to protect against abusive practices that push some pensions beyond what makes economic sense in light of the employee's salary before retirement. The fiscal problems currently being experienced by many state and local governments should not be solved predominantly on the backs of pension claimants. 